\title{
STRUCTURE AND VIBRATIONAL SPECTRA OF URANYL DINITRATE COMPLEXES WITH WATER AND DMSO
}

\author{
M. B. Shundalau, ${ }^{*}$ A. A. Zazhogin, A. P. Zazhogin, \\ A. I. Komyak, and D. S. Umreiko
}

UDC 539.19

Structural models were designed and spectral characteristics were computed based on DFT calculations for uranyl dinitrate complexes with $\mathrm{H}_{2} \mathrm{O}$ and DMSO $\left[\mathrm{UO}_{2}\left(\mathrm{NO}_{3}\right)_{2} \cdot 2 \mathrm{DMSO}, \mathrm{UO}_{2}\left(\mathrm{NO}_{3}\right)_{2} \cdot 2 \mathrm{H}_{2} \mathrm{O} \cdot 2 \mathrm{DMSO}\right.$, $\mathrm{UO}_{2}\left(\mathrm{NO}_{3}\right)_{2} \cdot 2 \mathrm{H}_{2} \mathrm{O} \cdot 4 \mathrm{DMSO}$. Vibrational IR and Raman spectra of $\mathrm{UO}_{2}\left(\mathrm{NO}_{3}\right)_{2} \cdot 2 \mathrm{DMSO}$ were interpreted using models for bidentate and monodentate coordination of nitrate ions to uranyl. Several spectral signatures that characterized DMSO complexation in the second coordination sphere were identified and had analytical significance.

Keywords: density functional theory, effective core potential, infrared spectrum, Raman spectrum, uranyl dinitrate, dimethylsulfoxide, coordination complex.

Introduction. Compounds of hexavalent uranium [U(VI)] form numerous complexes with organic and inorganic ligands [1-3]. Because the fragments of such complexes are labile, they can play an important role in the migration of $U$ ions in degraded surface layers of nuclear materials and nuclear wastes [4]. Theoretical investigations of complexation together with experimental measurements of the characteristics of U(VI) complexes allowed definite trends in their structures and physicochemical properties to be identified [5]. Structural models were built and vibrational spectra were interpreted earlier for complexes of tetravalent $\left(\mathrm{UCl}_{4}\right)$ and hexavalent $\left(\mathrm{UO}_{2}^{2+}\right)$ uranium with polar organic ligands in the first coordination sphere $\left(\mathrm{UCl}_{4} \cdot 2 \mathrm{DMF}, \mathrm{UCl}_{4} \cdot 2 \mathrm{DMSO}, \mathrm{UCl}_{4} \cdot 2 \mathrm{HMPA}, \mathrm{UO}_{2} \mathrm{Cl}_{2} \cdot 2 \mathrm{HMPA}\right)$ based on quantum-chemical calculations and spectroscopic measurements [6-8]. Density functional theory computations demonstrated that the complex structural models were adequate and agreed with existing experimental data.

The present work discusses the structures of uranyl dinitrate $\left[\mathrm{UO}_{2}\left(\mathrm{NO}_{3}\right)_{2}\right]$ complexes with $\mathrm{H}_{2} \mathrm{O}$ and DMSO based on quantum-chemical calculations and analyses of IR and Raman spectra.

Experimental and Calculations. IR absorption spectra of $\mathrm{UO}_{2}\left(\mathrm{NO}_{3}\right)_{2} \cdot 2 \mathrm{DMSO}$ in mineral oil were recorded on a Bruker IFS-113 Fourier spectrometer in the range 3700-600 $\mathrm{cm}^{-1}$; Raman spectra of solid $\mathrm{UO}_{2}\left(\mathrm{NO}_{3}\right)_{2} \cdot 2 \mathrm{DMSO}, 3300-50 \mathrm{~cm}^{-1}$. Excitation used radiation from an Ar-ion laser with $\lambda=514.5 \mathrm{~nm}$ and power $200 \mathrm{~mW}$.

The applied quantum-chemistry program GAMESS-US [9, 10] was used to optimize the equilibrium structures and to calculate force fields, eigen frequencies of harmonic vibrations, and intensities in IR and Raman spectra of $\mathrm{UO}_{2}\left(\mathrm{NO}_{3}\right)_{2} \cdot 2 \mathrm{DMSO}, \mathrm{UO}_{2}\left(\mathrm{NO}_{3}\right)_{2}, \mathrm{UO}_{2}\left(\mathrm{NO}_{3}\right)_{2} \cdot 2 \mathrm{H}_{2} \mathrm{O}, \mathrm{UO}_{2}\left(\mathrm{NO}_{3}\right)_{2} \cdot 2 \mathrm{H}_{2} \mathrm{O} \cdot 2 \mathrm{DMSO}$, and $\mathrm{UO}_{2}\left(\mathrm{NO}_{3}\right)_{2} \cdot 2 \mathrm{H}_{2} \mathrm{O} \cdot 4 \mathrm{DMSO}$ and their fragments. The results were visualized using the MacMolPlt [11] and ORTEP [12] programs. The relativistic effective core potential (RECP) LANL2DZ was used for the U atom [13] and replaced the 78 inner electrons. A DZ-basis set that was specially developed for this RECP was used for the remaining $U$ electrons. The other atoms were described based on the standard full-electron basis cc-pVDZ of Dunning [14]. The RECP and the corresponding basis sets were generated using the Extensible Computational Chemistry Environment Basis Set Database [15-17]. The hybrid exchange-correlated functional B3LYP was also used in all calculations [18-20].

Results and Discussion. Figure 1 shows portions of the experimental IR and Raman spectra of $\mathrm{UO}_{2}\left(\mathrm{NO}_{3}\right)_{2} \cdot 2 \mathrm{DMSO}$ in the regions 1600-600 and 1650-50 $\mathrm{cm}^{-1}$. Table 1 compares the experimental data with the calculated harmonic vibrational frequencies of the anhydrous complex of $\mathrm{UO}_{2}\left(\mathrm{NO}_{3}\right)_{2}$ with DMSO in addition to its fragments and hydrates. Weak bands in

\footnotetext{
${ }^{*}$ To whom correspondence should be addressed.
}

Belarusian State University, 4 Nezavisimost' Ave., Minsk, 220030, Belarus; e-mail: shundalov@bsu.by. Translated from Zhurnal Prikladnoi Spektroskopii, Vol. 82, No. 1, pp. 29-36, January-February, 2015. Original article submitted May $16,2014$. 


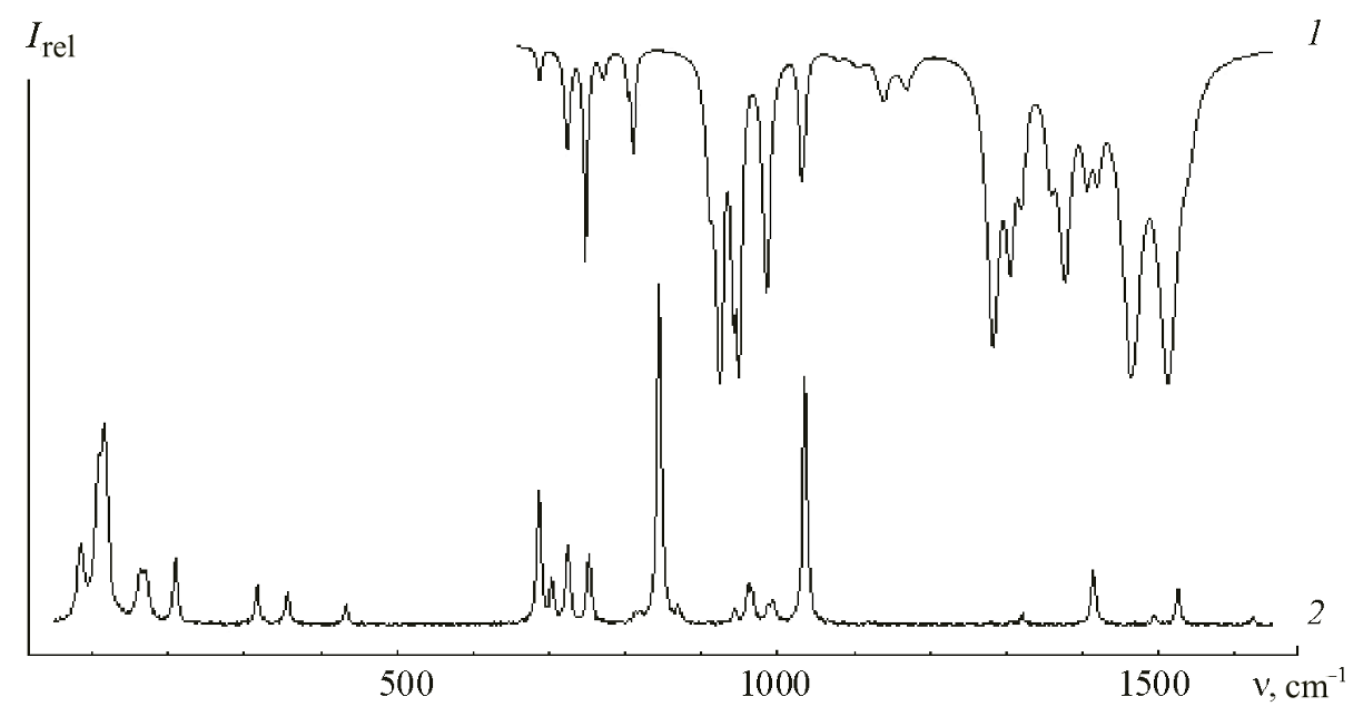

Fig. 1. IR (1) and Raman (2) spectra of $\mathrm{UO}_{2}\left(\mathrm{NO}_{3}\right)_{2} \cdot 2 \mathrm{DMSO}$.
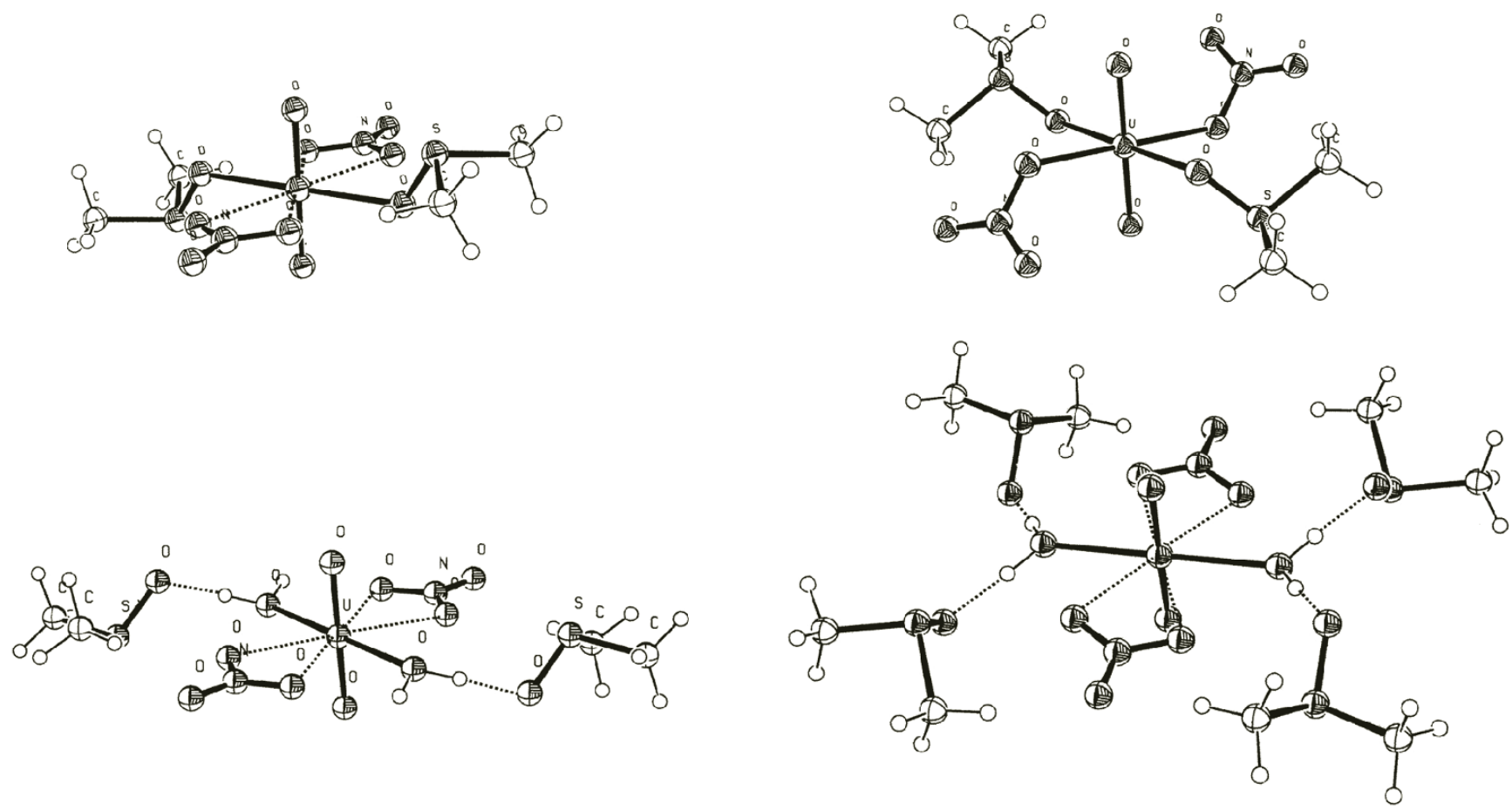

Fig. 2. Equilibrium structures of complexes with bidentate and monodentate nitrate $\left[\mathrm{UO}_{2}\left(\mathrm{NO}_{3}\right)_{2} \cdot 2 \mathrm{DMSO}\right](\mathrm{a}, \mathrm{b}) ; \mathrm{UO}_{2}\left(\mathrm{NO}_{3}\right)_{2} \cdot 2 \mathrm{H}_{2} \mathrm{O} \cdot 2 \mathrm{DMSO}$ (c); and $\mathrm{UO}_{2}\left(\mathrm{NO}_{3}\right)_{2} \cdot 2 \mathrm{H}_{2} \mathrm{O} \cdot 4 \mathrm{DMSO}(\mathrm{d})$.

the IR spectrum at $\sim 3440,3193,2725,2673,2545,1079$, and $724 \mathrm{~cm}^{-1}$ and strong ones at 2953, 2924, 2870, 2853, 1465, 1377,1305 , and $1170 \mathrm{~cm}^{-1}$ belonged to the solvent (mineral oil). Therefore, they are not included in Table 1. Furthermore, broad bands and weak lines in the short-wavelength region $\left(3370-3300 \mathrm{~cm}^{-1}\right.$ ) were consistent with traces of $\mathrm{H}_{2} \mathrm{O}$ in the sample. This allowed the asymmetric shoulder of the strong band at $1513 \mathrm{~cm}^{-1}$ to be interpreted as a $\mathrm{H}_{2} \mathrm{O}$ bending vibration; the weak line at $\sim 356 \mathrm{~cm}^{-1}$, a $\mathrm{H}_{2} \mathrm{O}$ librational vibration. 
TABLE 1. Calculated and Experimental Vibrational Frequencies $\left(v, \mathrm{~cm}^{-1}\right)$ of $\mathrm{UO}_{2}\left(\mathrm{NO}_{3}\right)_{2} \cdot 2 \mathrm{DMSO}(\mathrm{I}), \mathrm{UO}_{2}\left(\mathrm{NO}_{3}\right)_{2}$ (II), $\mathrm{UO}_{2}\left(\mathrm{NO}_{3}\right)_{2} \cdot 2 \mathrm{H}_{2} \mathrm{O}(\mathrm{III}), \mathrm{UO}_{2}\left(\mathrm{NO}_{3}\right)_{2} \cdot 2 \mathrm{H}_{2} \mathrm{O} \cdot 2 \mathrm{DMSO}(\mathrm{IV})$, and $\mathrm{UO}_{2}\left(\mathrm{NO}_{3}\right)_{2} \cdot 2 \mathrm{H}_{2} \mathrm{O} \cdot 4 \mathrm{DMSO}(\mathrm{V})$ and Their Fragments

\begin{tabular}{|c|c|c|c|c|c|c|c|c|c|c|c|c|}
\hline \multirow{3}{*}{ Assignment } & \multicolumn{4}{|c|}{ I } & \multicolumn{2}{|c|}{$\begin{array}{l}\text { Fragments: } \mathrm{UO}_{2}^{2+}, \\
\mathrm{NO}_{3}^{-} \text {, or DMSO }\end{array}$} & \multicolumn{2}{|l|}{ II } & \multicolumn{2}{|l|}{ III } & \multirow{3}{*}{$\begin{array}{c}\text { IV } \\
v_{\text {calc }}\end{array}$} & \multirow{3}{*}{$\begin{array}{c}\mathrm{V} \\
v_{\text {calc }}\end{array}$} \\
\hline & \multicolumn{2}{|c|}{$v_{\exp }$} & \multicolumn{2}{|c|}{$v_{\text {calc }}$} & \multirow[b]{2}{*}{$v_{\exp }$} & \multirow[b]{2}{*}{$v_{\text {calc }}$} & \multirow[b]{2}{*}{$v_{\exp }$} & \multirow[b]{2}{*}{$v_{\text {calc }}$} & \multirow[b]{2}{*}{$v_{\exp }$} & \multirow[b]{2}{*}{$v_{\text {calc }}$} & & \\
\hline & IR & $\begin{array}{c}\text { Raman } \\
\text { scattering }\end{array}$ & $\mathrm{BC}$ & $\mathrm{MC}$ & & & & & & & & \\
\hline$v_{\mathrm{as}}\left(\mathrm{CH}_{3}\right)$ & & & 3183 & 3185 & & 3154 & & & & & 3180 & 3213 \\
\hline$v_{\mathrm{as}}\left(\mathrm{CH}_{3}\right)$ & & & 3182 & 3178 & & 3143 & & & & & 3169 & 3168 \\
\hline$v_{\mathrm{as}}\left(\mathrm{CH}_{3}\right)$ & 3013 & 3019 & 3175 & 3164 & & 3137 & & & & & 3145 & 3151 \\
\hline$v_{\mathrm{as}}\left(\mathrm{CH}_{3}\right)$ & & & 3162 & 3148 & 2999 [21] & 3131 & & & & & 3140 & 3123 \\
\hline$v_{\mathrm{s}}\left(\mathrm{CH}_{3}\right)$ & & 2928 & 3054 & 3054 & & 3030 & & & & & 3035 & 3043 \\
\hline$v_{\mathrm{S}}\left(\mathrm{CH}_{3}\right)$ & & & 3052 & 3034 & 2915 [21] & 3024 & & & & & 3030 & 3000 \\
\hline Overtone 1406 & & 2803 & & & & & & & & & & \\
\hline $\begin{array}{l}v_{\mathrm{s}}(\mathrm{NO}) \mathrm{BC} \\
\left(v_{3}\left(\mathrm{NO}_{3}^{-}\right)\right)\end{array}$ & & 1526 & 1623 & 1627 & \multirow[t]{2}{*}{$1390[1]$} & \multirow[t]{2}{*}{1381} & $1635[22]$ & 1676 & \multirow[t]{2}{*}{$1605[5]$} & 1666 & 1622 & 1594 \\
\hline$v_{\mathrm{as}}(\mathrm{NO}) \mathrm{BC}\left(v_{3}\left(\mathrm{NO}_{3}^{-}\right)\right)$ & 1513 & & 1614 & 1630 & & & $1616[22]$ & 1663 & & 1654 & 1612 & 1584 \\
\hline Overtone 748 & & 1495 & & & & & & & & & & \\
\hline$\delta_{\mathrm{as}}\left(\mathrm{CH}_{3}\right)$ & & & 1456 & 1466 & $1438[21]$ & 1449 & & & & & 1460 & 1459 \\
\hline$\delta_{\mathrm{as}}\left(\mathrm{CH}_{3}\right)$ & 1421 & 1420 & 1432 & 1434 & & 1429 & & & & & 1435 & 1445 \\
\hline$\delta_{\mathrm{as}}\left(\mathrm{CH}_{3}\right)$ & & 1415 & 1422 & 1427 & 1414 [23] & 1428 & & & & & 1422 & 1430 \\
\hline$\delta_{\mathrm{as}}\left(\mathrm{CH}_{3}\right)$ & 1406 & & 1408 & 1412 & 1407 [21] & 1413 & & & & & 1410 & 1421 \\
\hline$v_{\mathrm{s}}(\mathrm{NO})\left(v_{3}\left(\mathrm{NO}_{3}^{-}\right)\right)$ & & & 1328 & 1346 & & & $1235[22]$ & 1249 & $1280[5]$ & 1290 & 1340 & 1327 \\
\hline$v_{\mathrm{as}}(\mathrm{NO}) \mathrm{MC}\left(v_{3}\left(\mathrm{NO}_{3}^{-}\right)\right)$ & 1321 & 1322 & & 1331 & $1390[1]$ & 1381 & & & & & & \\
\hline$v_{\mathrm{as}}(\mathrm{NO}) \mathrm{BC}\left(v_{3}\left(\mathrm{NO}_{3}^{-}\right)\right)$ & 1283 & 1280 & 1316 & & & & $1220[22]$ & 1236 & $1280[5]$ & 1281 & 1333 & 1323 \\
\hline$\delta_{\mathrm{s}}\left(\mathrm{CH}_{3}\right)$ & & 1310 & 1327 & 1339 & \multirow{2}{*}{$-1313[21]$} & \multirow{2}{*}{1325} & & & & & 1313 & 1321 \\
\hline$\delta_{\mathrm{s}}\left(\mathrm{CH}_{3}\right)$ & & & 1312 & 1337 & & & & & & & 1312 & 1295 \\
\hline$\delta_{\mathrm{s}}\left(\mathrm{CH}_{3}\right)$ & & & 1301 & 1308 & \multirow{2}{*}{$1290[23]$} & \multirow{2}{*}{1299} & & & & & 1290 & 1314 \\
\hline$\delta_{\mathrm{s}}\left(\mathrm{CH}_{3}\right)+\delta\left(\mathrm{NO}_{3}\right)$ & & & 1295 & 1307 & & & & & & & 1289 & 1310 \\
\hline C. $705+434$ & 1140 & & & & & & & & & & & \\
\hline C. $950+170$ & & 1120 & & & & & & & & & & \\
\hline$v_{\mathrm{s}}(\mathrm{NO}) \mathrm{BC}\left(v_{1}\left(\mathrm{NO}_{3}^{-}\right)\right)$ & & 1036 & 1064 & 1012 & \multirow{2}{*}{$1050[1]$} & 1054 & 1010 [22] & 1041 & $1027[5]$ & 1061 & 1071 & 1059 \\
\hline$v_{\mathrm{as}}(\mathrm{NO}) \mathrm{BC}\left(v_{1}\left(\mathrm{NO}_{3}^{-}\right)\right)$ & 1035 & & 1063 & 995 & & & & & $102,[2]$ & 1056 & 1071 & 1057 \\
\hline$\rho\left(\mathrm{CH}_{3}\right)$ & 1030 & & 1039 & 1042 & $954[21]$ & 1007 & & & & & 1025 & 1032 \\
\hline C. $911+85$ & & 995 & & & & & & & & & & \\
\hline$\rho\left(\mathrm{CH}_{3}\right)$ & 986 & 988 & 996 & 990 & $920[21]$ & 926 & & & & & 944 & 947 \\
\hline C. $803+163$ & & 967 & & & & & & & & & & \\
\hline C. $845+117$ & & 961 & & & & & & & & & & \\
\hline$v_{\mathrm{as}}(\mathrm{UO}) \mathrm{BC}\left(v_{3}\left(\mathrm{UO}_{3}^{2+}\right)\right)$ & 950 & & 952 & & $1020-800$ & 1090 & \begin{tabular}{|c|}
$990-965$ \\
{$[22]$}
\end{tabular} & 976 & $929[5]$ & 962 & 964 & 958 \\
\hline$v_{\mathrm{as}}(\mathrm{UO}) \mathrm{MC}\left(v_{3}\left(\mathrm{UO}_{3}^{2+}\right)\right)$ & 942 & 944 & & 947 & & & & & & & & \\
\hline$v(\mathrm{~S}=\mathrm{O}) \mathrm{BC}$ & 924 & & $\begin{array}{l}948 \\
939\end{array}$ & & $1039[21]$ & 1086 & & & & & $\begin{array}{l}991 \\
991\end{array}$ & $\begin{array}{c}1004 \\
997\end{array}$ \\
\hline$v(\mathrm{~S}=\mathrm{O}) \mathrm{MC}$ & 911 & & & $\begin{array}{l}928 \\
919 \\
\end{array}$ & & & & & & & & \\
\hline
\end{tabular}


TABLE 1 (continued)

\begin{tabular}{|c|c|c|c|c|c|c|c|c|c|c|c|c|}
\hline \multirow{3}{*}{ Assignment } & \multicolumn{4}{|c|}{ I } & \multicolumn{2}{|c|}{$\begin{array}{c}\text { Fragments: } \mathrm{UO}_{3}^{2+} \text {, } \\
\mathrm{NO}_{3}^{-} \text {, or DMSO }\end{array}$} & \multicolumn{2}{|l|}{ II } & \multicolumn{2}{|l|}{ III } & \multirow{3}{*}{$\begin{array}{c}\text { IV } \\
v_{\text {calc }}\end{array}$} & \multirow{3}{*}{$\begin{array}{c}\mathrm{V} \\
v_{\text {calc }}\end{array}$} \\
\hline & \multicolumn{2}{|r|}{$v_{\exp }$} & \multicolumn{2}{|c|}{$v_{\text {calc }}$} & \multirow[b]{2}{*}{$v_{\exp }$} & \multirow[b]{2}{*}{$v_{\text {calc }}$} & \multirow[b]{2}{*}{$v_{\exp }$} & \multirow[b]{2}{*}{$v_{\text {calc }}$} & \multirow[b]{2}{*}{$v_{\exp }$} & \multirow[b]{2}{*}{$v_{\text {calc }}$} & & \\
\hline & IR & $\begin{array}{c}\text { Raman } \\
\text { scattering }\end{array}$ & $\mathrm{BC}$ & MK & & & & & & & & \\
\hline$\rho\left(\mathrm{CH}_{3}\right)$ & & & 937 & 942 & $900[21]$ & 892 & & & & & 931 & 925 \\
\hline$\rho\left(\mathrm{CH}_{3}\right)$ & 870 & 870 & 909 & 915 & & 868 & & & & & 896 & 902 \\
\hline C. $686+163$ & & 850 & & & & & & & & & & \\
\hline$v_{\mathrm{s}}(\mathrm{UO})\left(v_{1}\left(\mathrm{UO}_{3}^{2+}\right)\right)$ & & 845 & 861 & 855 & $\begin{array}{c}900-780 \\
{[1,24]} \\
\end{array}$ & 993 & $895[22]$ & 885 & $855[25]$ & 872 & 875 & 872 \\
\hline$\rho\left(\mathrm{NO}_{3}\right)\left(\mathrm{v}_{2}\left(\mathrm{NO}_{3}^{-}\right)\right)$ & 811 & 814 & 819 & 813 & $830[1]$ & 995 & $798[22]$ & 807 & $803[5]$ & 810 & 815 & 814 \\
\hline C. $687+117$ & 803 & & & & & & & & & & & \\
\hline C. $687+85$ & 771 & & & & & & & & & & & \\
\hline $\begin{array}{l}\delta_{\mathrm{s}}\left(\mathrm{NO}_{3}\right) \mathrm{BC} \\
\left(v_{4}\left(\mathrm{NO}_{3}^{-}\right)\right)\end{array}$ & 748 & 753 & 755 & & \multirow{4}{*}{$720[1]$} & \multirow{4}{*}{734} & $722[22]$ & 756 & $748[5]$ & 747 & 763 & 748 \\
\hline $\begin{array}{l}\delta_{\mathrm{s}}\left(\mathrm{NO}_{3}\right) \mathrm{MC} \\
\left(\mathrm{v}_{4}\left(\mathrm{NO}_{3}^{-}\right)\right)\end{array}$ & & 725 & & 731 & & & & & & & & \\
\hline $\begin{array}{c}\delta_{\mathrm{as}}\left(\mathrm{NO}_{3}\right) \mathrm{BC} \\
\left(\mathrm{v}_{4}\left(\mathrm{NO}_{3}^{-}\right)\right) \\
\end{array}$ & 705 & 704 & 708 & & & & $689[22]$ & 709 & $748[5]$ & 715 & 711 & 727 \\
\hline$\delta_{\mathrm{as}}\left(\mathrm{NO}_{3}\right) \mathrm{MC}\left(\mathrm{v}_{4}\left(\mathrm{NO}_{3}^{-}\right)\right)$ & & & & 686 & & & & & & & & \\
\hline$v_{\mathrm{as}}(\mathrm{CS})$ & 687 & 687 & 687 & 692 & $698[21]$ & 649 & & & & & 674 & 664 \\
\hline$v_{\mathrm{S}}(\mathrm{CS})$ & & & 649 & 653 & $665[21]$ & 626 & & & & & 641 & 639 \\
\hline$\gamma(\mathrm{S}=\mathrm{O})$ & & 434 & 412 & 415 & $378[23]$ & 368 & & & & & 436 & $\begin{array}{l}424, \\
389\end{array}$ \\
\hline$\rho(S=O)$ & & 317 & 345 & 328 & $329[23]$ & 310 & & & & & 339 & $\begin{array}{l}355, \\
335 \\
\end{array}$ \\
\hline$\delta(\mathrm{OUO})+\delta(\mathrm{CSC})$ & & & 300 & 300 & & & & & & & & \\
\hline$\delta(\mathrm{CSC})$ & & & 291 & 297 & $305[23]$ & 284 & & & & & 295 & 299 \\
\hline \multirow{2}{*}{$\delta(\mathrm{OUO})\left(\mathrm{v}_{2}\left(\mathrm{UO}_{3}^{2+}\right)\right)$} & & & 284 & 259 & $290-240$ & 259 & $265-250$ & & & & 268 & 278 \\
\hline & & & 277 & 248 & {$[1,22]$} & 239 & {$[22]$} & 319 & $190[25]$ & & 255 & 261 \\
\hline$\tau\left(\mathrm{CH}_{3}\right)$ & & & 270 & 285 & & 188 & & & & & 243 & 247 \\
\hline Libration $\mathrm{UO}_{2}$ & & & 216 & 205 & & & & 249 & & 271 & 200 & 215 \\
\hline \multirow{4}{*}{$v(\mathrm{U} \ldots \mathrm{O})$ (nitrate) } & & \multirow{4}{*}{209} & 214 & \multirow{2}{*}{316} & & & \multirow{4}{*}{$252[25]$} & & \multirow{2}{*}{$264[25]$} & 252 & 246 & 254 \\
\hline & & & 209 & & & & & & & 284 & 240 & 252 \\
\hline & & & 208 & 303 & & & & & $256[25]$ & 246 & 234 & 224 \\
\hline & & & 199 & 303 & & & & & $250[25]$ & 229 & 221 & 223 \\
\hline Libration $\mathrm{NO}_{3}$ & & & 190 & & & & & & & & 203 & 194 \\
\hline \multirow{4}{*}{ Libration $\mathrm{DMSO}+\delta\left(\mathrm{NO}_{3}^{-}\right)$} & & 171 & 182 & & & & & & & & 158 & 172 \\
\hline & & $1 / 1$ & 164 & & & & & & & 276 & 157 & 130 \\
\hline & & & 159 & & & & & & & & 128 & 128 \\
\hline & & 163 & 155 & & & & & 157 & & 157 & 112 & 123 \\
\hline & & 117 & & & & & & & & & & \\
\hline Phonon lines & & 108 & & & & & & & & & & \\
\hline & & 85 & & & & & & & & & & \\
\hline
\end{tabular}

Note. The presence of two (or four) identical fragments ( $\mathrm{NO}_{3}^{-}, \mathrm{H}_{2} \mathrm{O}$, or DMSO) in the complexes doubled the frequencies, the splitting of which was as a rule $<3 \mathrm{~cm}^{-1}$. Therefore, only one (the greater) wavenumber is given. $\mathrm{C}$. is a combination frequency; $\mathrm{BC}$, bidentate coordination; MC, monodentate coordination; $v$, stretching; $\delta$, bending; $\rho$, rocking; $\gamma$, out-of-plane; $\tau$, torsion; $\mathrm{s}$, symmetric; as, antisymmetric vibrations. 


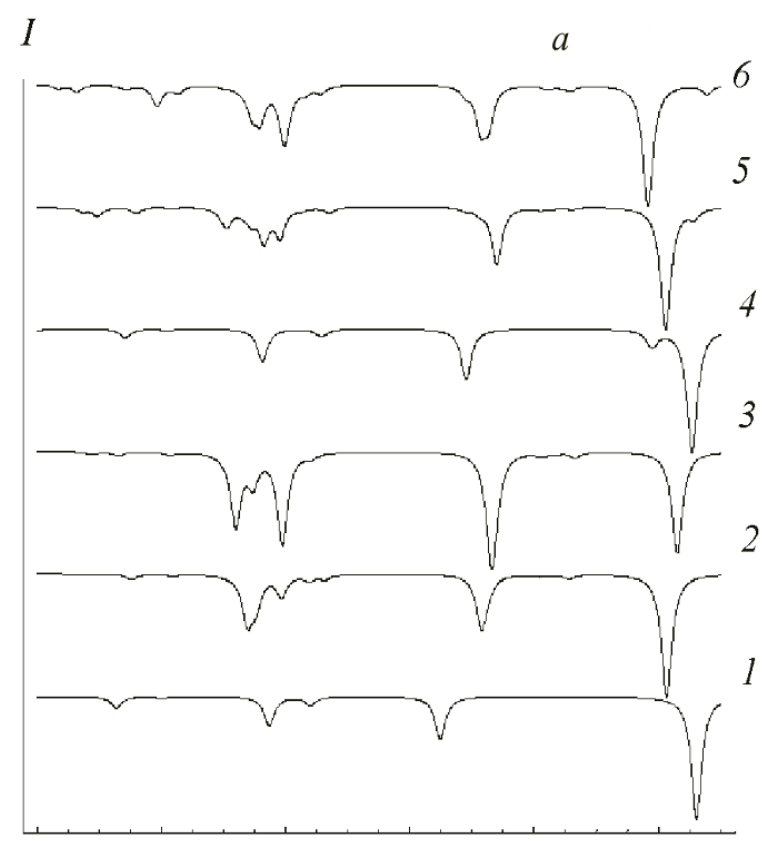

600

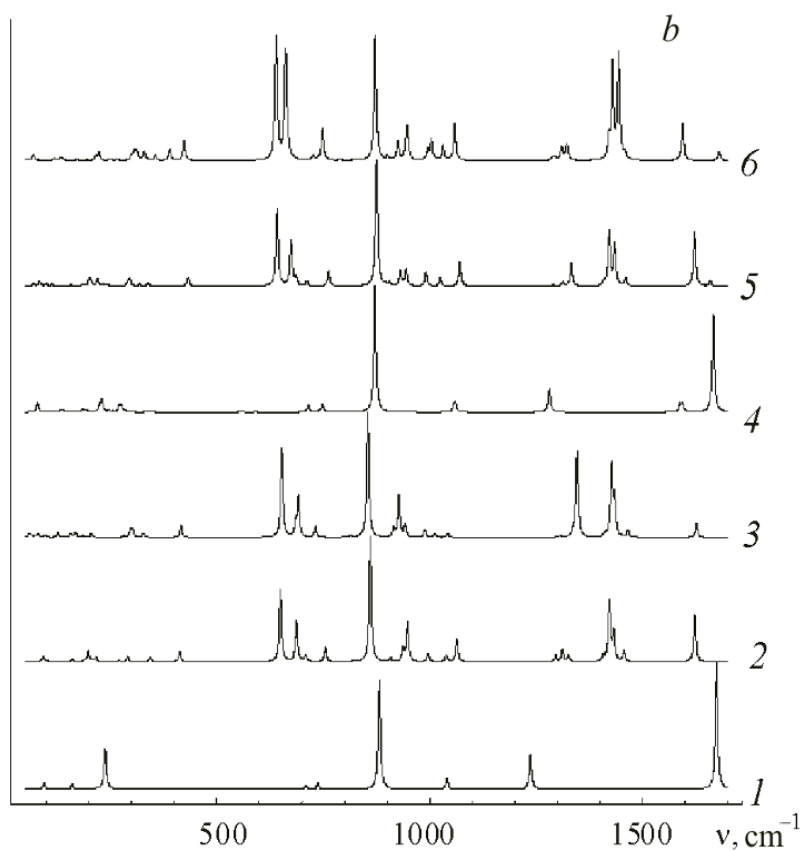

Fig. 3. Calculated IR (a) and Raman (b) spectra of $\mathrm{UO}_{2}\left(\mathrm{NO}_{3}\right)_{2}(1) ; \mathrm{UO}_{2}\left(\mathrm{NO}_{3}\right)_{2} \cdot 2 \mathrm{DMSO}$

(bidentate and monodentate coordination) (2, 3); $\mathrm{UO}_{2}\left(\mathrm{NO}_{3}\right)_{2} \cdot 2 \mathrm{H}_{2} \mathrm{O}$ (4); $\mathrm{UO}_{2}\left(\mathrm{NO}_{3}\right)_{2} \cdot 2 \mathrm{H}_{2} \mathrm{O} \cdot 2 \mathrm{DMSO}(5)$; and $\mathrm{UO}_{2}\left(\mathrm{NO}_{3}\right)_{2} \cdot 2 \mathrm{H}_{2} \mathrm{O} \cdot 4 \mathrm{DMSO}(6)$.

The starting model of the $\mathrm{UO}_{2}\left(\mathrm{NO}_{3}\right)_{2} \cdot 2 \mathrm{DMSO}$ structure was based on bidentate nitrate coordination in the equatorial plane of the uranyl, which was a more stable configuration than the monodentate form [1]. The model equilibrium structure for bidentate coordinated $\mathrm{UO}_{2}\left(\mathrm{NO}_{3}\right)_{2} \cdot 2 \mathrm{DMSO}$ had $C_{i}$ symmetry. Its structure was analogous to those of $\mathrm{UO}_{2}\left(\mathrm{NO}_{3}\right)_{2}$ complexes with two DMF, dibutylformamide, and dicyclohexylformamide molecules [5]. The organic ligands were located in transpositions relative to the central $U$ atom with the oxygen atoms of the organic ligands situated in the uranyl equatorial plane. Spectra of $\mathrm{UO}_{2}\left(\mathrm{NO}_{3}\right)_{2} \cdot 2 \mathrm{DMSO}$ in the region $<1000 \mathrm{~cm}^{-1}$ showed an anomalously large number of bands and lines that could not be adequately interpreted based only on bidentate $\mathrm{NO}_{3}{ }^{-}$coordination. Therefore, we also examined the version with monodentate nitrate coordinated to uranyl. Because the computations indicated that the energy of monodentate coordinated $\mathrm{UO}_{2}\left(\mathrm{NO}_{3}\right)_{2} \cdot 2 \mathrm{DMSO}$ was $\sim 51 \mathrm{~kJ} / \mathrm{mol}$ greater than that of the bidentate complex, it was assumed that the intensities of the corresponding bands and lines of the first complex would be significantly less than those of the second. The equilibrium configurations were found (Fig. 2) and vibrational spectra (Fig. 3) of the separate fragments $\left[\mathrm{UO}_{3}^{2+}, \mathrm{NO}_{3}^{-}, \mathrm{DMSO}^{-} \mathrm{H}_{2} \mathrm{O}\right.$, $\left.\mathrm{UO}_{2}\left(\mathrm{NO}_{3}\right)_{2}\right]$ were calculated for a comprehensive analysis of the spectral characteristics of the examined systems and for a determination of the spectral and structural features upon hydration of the complexes in the aforementioned approximation. The proposed structural models (Fig. 2) were based on an analysis of the ability to accommodate $\mathrm{H}_{2} \mathrm{O}$ and DMSO in the first (inner) coordination sphere of uranyl. Two factors could play the main role. These were the displacing power of the ligand (donor number $D)$ and steric issues. Although the first factor for organics was greater than for $\mathrm{H}_{2} \mathrm{O}\left(D_{\mathrm{DMSO}}=29, D_{\mathrm{H}_{2} \mathrm{O}}=\right.$ 14), the larger size of DMSO did not allow it to replace $\mathrm{H}_{2} \mathrm{O}$. Therefore, DMSO could be expelled into the outer coordination sphere of $\mathrm{UO}_{2}\left(\mathrm{NO}_{3}\right)_{2}$.

Structural and spectral characteristics of the isolated uranyl ion and DMSO molecule in the B3LYP/cc-pVDZ approximation and their agreement with experimental data were discussed by us previously [6, 7]. The standard designations $v_{1}$, totally symmetric stretching; $v_{2}$, doubly degenerate bending; and $v_{3}$, asymmetric stretching vibration were used to classify vibrations of the $\mathrm{UO}_{2}^{2+}$ fragment ( $D_{\infty h}$ symmetry).

The structure and vibrational spectrum of $\mathrm{NO}_{3}^{-}$were calculated for a model with point symmetry $D_{3 h}$ (free nitrate). The standard designations $v_{1}$, totally symmetric stretching, $v_{2}$; out-of-plane bending; $v_{3}$, doubly degenerate stretching; and $v_{4}$, doubly degenerate in-plane bending vibration were used to classify vibrations of the $\mathrm{NO}_{3}^{-}$fragment. 
Two models were also examined for the structure of isolated $\mathrm{UO}_{2}\left(\mathrm{NO}_{3}\right)_{2}$, i.e., bidentate and monodentate nitrates. In the first instance, an equilibrium geometry with $D_{2 h}$ symmetry was obtained. The lack of imaginary frequencies in the calculated spectrum confirmed that this configuration was stable. Neither of the models with symmetry limitations $\left(D_{2 h}, C_{i}\right.$, etc. produced an equilibrium configuration for monodentate coordination (calculated vibrational spectra of all models contained several imaginary frequencies). Optimization of the geometry of $\mathrm{UO}_{2}\left(\mathrm{NO}_{3}\right)_{2}$ with monodentate nitrates without symmetry limitations produced an equilibrium configuration with bidentate coordination. Thus, we supposed that free $\mathrm{UO}_{2}\left(\mathrm{NO}_{3}\right)_{2}$ with monodentate coordination was unstable. This structure could be stabilized either by coordination of additional ligands in the first coordination sphere of $\mathrm{UO}_{2}\left(\mathrm{NO}_{3}\right)_{2}$ or in a crystalline sample [22].

The calculated vibrational frequencies (taking into account typical errors of the used approximation), their sequences, and activities in IR and Raman spectra of isolated nitrate and bidentate nitrate coordinated to $\mathrm{UO}_{2}\left(\mathrm{NO}_{3}\right)_{2}$ corresponded to the published values $[1,22,26]$ (Table 1). The local symmetry of the nitrate fragment was reduced to $C_{2 v}$ for both bidentate and monodentate coordination. As a result, the doubly degenerate modes were split (for typical values, see the literature [1]). The presence of two nitrates in the complex (regardless of their coordination) caused additional splitting of each vibrational mode into two components that were symmetric and asymmetric relative to the complex center. The sizes of these splittings could differ substantially for bi- and monodentate coordinated nitrate (Table 1). This allowed vibrational spectra of $\mathrm{UO}_{2}\left(\mathrm{NO}_{3}\right)_{2} \cdot 2 \mathrm{DMSO}$ to be interpreted as follows.

Methyl stretching and bending vibrations are usually found in the ranges $2970-2870$ and $1450-1370 \mathrm{~cm}^{-1}$ [27]. The $\mathrm{CH}_{3}$ asymmetric stretching vibration in DMSO exceeded the indicated upper limit of the corresponding range [7, 21, 28]. This allowed strong lines at 3019 and $2928 \mathrm{~cm}^{-1}$ in the Raman spectrum to be assigned to asymmetric and symmetric $\mathrm{CH}_{3}$ stretching vibrations and a weak line at $2803 \mathrm{~cm}^{-1}$ to be interpreted as an overtone of a $\mathrm{CH}_{3}$ bending vibration $\left(1406 \mathrm{~cm}^{-1}\right)$. The weak line at $1495 \mathrm{~cm}^{-1}$ lay significantly higher than typical $\delta\left(\mathrm{CH}_{3}\right)$ values and was most likely an overtone of bending mode $v_{4}\left(\mathrm{NO}_{3}^{-}\right)$(bidentate coordination), the main frequency of which appeared as a strong band at $\sim 78 \mathrm{~cm}^{-1}$ in the IR spectrum, and a weak line at $\sim 753 \mathrm{~cm}^{-1}$ in the Raman spectrum. Bands and lines at 1421 (IR and Raman), 1415 (Raman), 1406 (IR), and $1310 \mathrm{~cm}^{-1}$ (Raman) were assigned to methyl bending vibrations based on calculations and the literature [7, 21, 28]. Bands and lines at 1030 (IR), 988 (Raman), 986 (IR), and $870 \mathrm{~cm}^{-1}$ (Raman and IR, shoulder) were assigned to rocking vibrations $\rho\left(\mathrm{CH}_{3}\right)[7,21,28]$.

Calculations predicted a significant $\left(164 \mathrm{~cm}^{-1}\right)$ long-wavelength shift for the $\mathrm{S}=\mathrm{O}$ stretching frequency in $\mathrm{UCl}_{4} \cdot 2 \mathrm{DMSO}$ [7]. This was confirmed in the experimental spectrum of $\mathrm{UCl}_{4} \cdot 2 \mathrm{DMSO}$ [21] because $v_{\mathrm{S}=\mathrm{O}}$ was shifted from $1039 \mathrm{~cm}^{-1}$ for pure DMSO to $940 \mathrm{~cm}^{-1}$ in the complex. Thus, it could be assumed that the quantum-chemical calculation using B3LYP/cc-pVDZ elevated $v_{\mathrm{S}=\mathrm{O}}$ in the complex by $\sim 20 \mathrm{~cm}^{-1}$. It could be proposed that these frequencies in the spectrum were located at $\sim 920 \mathrm{~cm}^{-1}$ because an analogous calculation for $\mathrm{UO}_{2}\left(\mathrm{NO}_{3}\right)_{2} \cdot 2 \mathrm{DMSO}$ with bidentate nitrates predicted for $v_{\mathrm{S}=\mathrm{O}}$ values of 948 (symmetric mode) and $939 \mathrm{~cm}^{-1}$ (asymmetric). Thus, the strong band at $924 \mathrm{~cm}^{-1}$ and the shoulder at $911 \mathrm{~cm}^{-1}$ in the IR spectrum of $\mathrm{UO}_{2}\left(\mathrm{NO}_{3}\right)_{2} \cdot 2 \mathrm{DMSO}$ were assigned to $\mathrm{S}=\mathrm{O}$ stretching vibrations for bi- and monodentate nitrates, respectively.

Frequencies of C-S stretching vibrations in pure DMSO are located at 695 (asymmetric mode) and $665 \mathrm{~cm}^{-1}$ (symmetric) [21, 28]. The first of these frequencies was shifted to $786 \mathrm{~cm}^{-1}$ for $\mathrm{UCl}_{4} \cdot 2 \mathrm{DMSO}$ [7, 21]. One of the four possible $\mathrm{C}-\mathrm{S}$ stretching modes (asymmetric relative to the $\mathrm{S}$ atom and symmetric relative to the $\mathrm{U}$ atom according to calculations) in the studied complex corresponded to a medium line at $687 \mathrm{~cm}^{-1}$ in the Raman spectrum. The corresponding band (asymmetric vibration relative to the $\mathrm{S}$ atom and $\mathrm{U}$ atom according to calculations) in the IR spectrum was very weak. Weak lines at 434 and $317 \mathrm{~cm}^{-1}$ in the Raman spectrum were assigned to out-of-plane bending $\gamma$ and rocking $\rho \mathrm{S}=\mathrm{O}$ vibrations (bands at 424 and $315 \mathrm{~cm}^{-1}$ in the spectrum of $\mathrm{UCl}_{4} \cdot 2 \mathrm{DMSO}$ corresponded to these vibrations [7, 21]).

Strong bands at 950 (bidentate coordination) and $942 \mathrm{~cm}^{-1}$ (monodentate) in the IR spectrum were assigned to the asymmetric $v_{3}$ uranyl stretching vibration; the strong line at $845 \mathrm{~cm}^{-1}$ in the Raman spectrum, to totally symmetric $v_{1}$. Bands and lines for uranyl $v_{2}$ bending mode were reported in the range $290-240 \mathrm{~cm}^{-1}$ depending on the type of coordination and number and type of ligands $[1,22,29]$. The $v_{2}$ vibration was assigned to a lower-frequency region $\left(210-190 \mathrm{~cm}^{-1}\right)[24,25]$. According to our calculations, which reproduced highly successfully the structure, and frequencies and intensities of uranyl stretching modes, the frequency of the $v_{2}$ vibration was $259 \mathrm{~cm}^{-1}$ and; therefore, fell into the first of the mentioned ranges. The calculated intensity of this mode was low. We supposed that this line was not observed in the Raman spectrum of the studied complex.

The doubly degenerate $v_{3}$ stretching vibration of complexed nitrate was split into high-frequency (symmetric component observed at $1526 \mathrm{~cm}^{-1}$ in the Raman spectrum; asymmetric, $1513 \mathrm{~cm}^{-1}$ in the IR spectrum) and low-frequency 
$\left(\sim 1280 \mathrm{~cm}^{-1}\right.$ in IR and Raman) modes [1]. Other nitrate vibrational frequencies appeared near 1035 (IR and Raman, $v_{1}$ ), 811 (IR, out-of-plane $v_{2}$ ), 750 (IR and Raman, symmetric component of $v_{4}$ ), and $705 \mathrm{~cm}^{-1}$ (IR and Raman, asymmetric component of $\left.v_{4}\right)$. The calculated and experimental data $[1,22,26]$ also agreed.

Frequencies of coordinated U...O stretching vibrations were reported at $\sim 200 \mathrm{~cm}^{-1}$ for bidentate nitrate coordination. This allowed a weak line at $209 \mathrm{~cm}^{-1}$ in the Raman spectrum to be assigned to $v_{\mathrm{U}} \ldots \mathrm{O}$ (the mode at $199 \mathrm{~cm}^{-1}$ was the strongest of the four vibrations of this type predicted by the calculations). Two weak lines at 171 and $163 \mathrm{~cm}^{-1}$ corresponded according to the calculations to ligand (DMSO) bending vibrations relative to uranyl. The lower-frequency region contained according to the calculations numerous complicated mixed bending modes of the ligands and uranyl. The frequencies and shapes of these vibrations had little information value and are not given in Table 1. Two medium lines $\left(117\right.$ and $\left.108 \mathrm{~cm}^{-1}\right)$ and a weak line at $\sim 85 \mathrm{~cm}^{-1}$ in the Raman spectrum were assigned to crystal-lattice vibrations.

Hydration of $\mathrm{UO}_{2}\left(\mathrm{NO}_{3}\right)_{2}$ decreased the high-frequency component of the $v_{3}\left(\mathrm{NO}_{3}{ }^{-}\right)$vibration to 1635 and $1616 \mathrm{~cm}^{-1}$ for $\mathrm{UO}_{2}\left(\mathrm{NO}_{3}\right)_{2}$ [22] and $1605 \mathrm{~cm}^{-1}$ for $\mathrm{UO}_{2}\left(\mathrm{NO}_{3}\right)_{2} \cdot 2 \mathrm{H}_{2} \mathrm{O}$ [5]. This trend was predicted by our calculations [1676 and 1663 $\mathrm{cm}^{-1}$ for $\mathrm{UO}_{2}\left(\mathrm{NO}_{3}\right)_{2} ; 1666$ and $1654 \mathrm{~cm}^{-1}$ for $\mathrm{UO}_{2}\left(\mathrm{NO}_{3}\right)_{2} \cdot 2 \mathrm{H}_{2} \mathrm{O} ; 1622$ and $1612 \mathrm{~cm}^{-1}$ for $\mathrm{UO}_{2}\left(\mathrm{NO}_{3}\right)_{2} \cdot 2 \mathrm{H}_{2} \mathrm{O} \cdot 2 \mathrm{DMSO}$; and 1594 and $1584 \mathrm{~cm}^{-1}$ for $\mathrm{UO}_{2}\left(\mathrm{NO}_{3}\right)_{2} \cdot 2 \mathrm{H}_{2} \mathrm{O} \cdot 4 \mathrm{DMSO}$. Conversely, the frequency tended to increase for the low-frequency component of this vibration $\left\{1235\right.$ and $1220 \mathrm{~cm}^{-1}$ for $\mathrm{UO}_{2}\left(\mathrm{NO}_{3}\right)_{2}$ [22] and $1280 \mathrm{~cm}^{-1}$ for $\left.\mathrm{UO}_{2}\left(\mathrm{NO}_{3}\right)_{2} \cdot 2 \mathrm{H}_{2} \mathrm{O}[5]\right\}$, which in general was confirmed by theoretical calculations [1249 and $1236 \mathrm{~cm}^{-1}$ for $\mathrm{UO}_{2}\left(\mathrm{NO}_{3}\right)_{2} ; 1290$ and $1281 \mathrm{~cm}^{-1}$ for $\mathrm{UO}_{2}\left(\mathrm{NO}_{3}\right)_{2} \cdot 2 \mathrm{H}_{2} \mathrm{O} ; 1340$ and $1333 \mathrm{~cm}^{-1}$ for $\mathrm{UO}_{2}\left(\mathrm{NO}_{3}\right)_{2} \cdot 2 \mathrm{H}_{2} \mathrm{O} \cdot 2 \mathrm{DMSO} ; 1327$ and $1323 \mathrm{~cm}^{-1}$ for $\left.\mathrm{UO}_{2}\left(\mathrm{NO}_{3}\right)_{2} \cdot 2 \mathrm{H}_{2} \mathrm{O} \cdot 4 \mathrm{DMSO}\right]$. The situation was analogous for $v_{1}\left(\mathrm{NO}_{3}{ }^{-}\right)$and $v_{2}\left(\mathrm{NO}_{3}{ }^{-}\right)\left\{1010\right.$ and $798 \mathrm{~cm}^{-1}$ for $\mathrm{UO}_{2}\left(\mathrm{NO}_{3}\right)_{2}$ [22]; 1027 and $803 \mathrm{~cm}^{-1}$ for $\mathrm{UO}_{2}\left(\mathrm{NO}_{3}\right)_{2} \cdot 2 \mathrm{H}_{2} \mathrm{O}$ [5] (experimental); 1041 and $807 \mathrm{~cm}^{-1}$ for $\mathrm{UO}_{2}\left(\mathrm{NO}_{3}\right)_{2} ; 1061$ and $810 \mathrm{~cm}^{-1}$ for $\mathrm{UO}_{2}\left(\mathrm{NO}_{3}\right)_{2} \cdot 2 \mathrm{H}_{2} \mathrm{O} ; 1071$ and $815 \mathrm{~cm}^{-1}$ for $\mathrm{UO}_{2}\left(\mathrm{NO}_{3}\right)_{2} \cdot 2 \mathrm{H}_{2} \mathrm{O} \cdot 2 \mathrm{DMSO} ; 1059$ and $814 \mathrm{~cm}^{-1}$ for $\mathrm{UO}_{2}\left(\mathrm{NO}_{3}\right)_{2} \cdot 2 \mathrm{H}_{2} \mathrm{O} \cdot 4 \mathrm{DMSO}$ (calculated) $\}$. Consistent tendencies were not observed for the $v_{4}\left(\mathrm{NO}_{3}^{-}\right)$mode (Table 1).

Hydration of $\mathrm{UO}_{2}\left(\mathrm{NO}_{3}\right)_{2}$ caused frequencies to decrease for asymmetric $v_{3}\left(\mathrm{UO}_{3}^{2+}\right)$ and symmetric $v_{1}\left(\mathrm{UO}_{3}^{2+}\right)$ uranyl stretching vibrations $\left\{\sim 980\right.$ and $895 \mathrm{~cm}^{-1}$ for $\mathrm{UO}_{2}\left(\mathrm{NO}_{3}\right)_{2}$ [22] and 929 and $855 \mathrm{~cm}^{-1}$ for $\mathrm{UO}_{2}\left(\mathrm{NO}_{3}\right)_{2} \cdot 2 \mathrm{H}_{2} \mathrm{O}$ [5] (experimental); 976 and $885 \mathrm{~cm}^{-1}$ for $\mathrm{UO}_{2}\left(\mathrm{NO}_{3}\right)_{2}$; and 962 and $872 \mathrm{~cm}^{-1}$ for $\mathrm{UO}_{2}\left(\mathrm{NO}_{3}\right)_{2} \cdot 2 \mathrm{H}_{2} \mathrm{O}$ (calculated) $\}$. Insertion of additional ligands into the second coordination sphere had practically no effect on these frequencies (Table 1).

Conclusions. Quantum-chemical modeling of the structure of a $\mathrm{UO}_{2}\left(\mathrm{NO}_{3}\right)_{2}$ complex with two DMSO molecules as electron-donating organic ligands predicted the existence of two stable configurations of $C_{i}$ symmetry with bidentate and monodentate nitrate coordination to the central $U$ atom. Vibrational IR and Raman spectra of the complex could be interpreted sufficiently completely only by assuming that both coordination types were present. Formation of the complexes was accompanied by splitting of bands and lines of nitrate vibrations and their shifts to short and long wavelengths that were predicted adequately by the calculations. The observed spectral shifts of the $\mathrm{S}=\mathrm{O}$ and nitrate vibrational frequencies could be used for analytical purposes.

\section{REFERENCES}

1. L. V. Volod'ko, A. I. Komyak, and D. S. Umreiko, Uranyl Compounds [in Russian], Vol. 1, BGU, Minsk (1981).

2. C. Clavaguera-Sarrio, S. Hoyau, N. Ismail, and C. J. Marsden, J. Phys. Chem. A, 107, 4515-4525 (2003).

3. R. G. Denning, J. Phys. Chem. A, 111, 4125-4143 (2007).

4. L. R. Morss, N. M. Edelstein, and J. Fuger (Eds.), The Chemistry of the Actinide and Transactinide Elements, $3^{\text {rd }}$ edn., Springer, Dordrecht [London] (2006).

5. A. Prestianni, L. Joubert, A. Chagnes, G. Cote, M.-N. Ohnet, C. Rabbe, M.-C. Charbonnel, and C. Adamo, J. Phys. Chem. A, 114, 10878-10884 (2010).

6. D. S. Umreiko, M. B. Shundalov, A. P. Zazhogin, and A. I. Komyak, Zh. Prikl. Spektrosk., 77, No. 4, 550-555 (2010).

7. M. B. Shundalov, P. C. Chibirai, A. I. Komyak, A. P. Zazhogin, and D. S. Umreiko, Zh. Prikl. Spektrosk., 79, No. 2, 181-188 (2012).

8. M. B. Shundalau, A. I. Komiak, A. P. Zajogin, and D. S. Umreiko, J. Spectrosc. Dyn., 3, 4 (2013).

9. M. W. Schmidt, K. K. Baldrige, J. A. Boatz, S. T. Elbert, M. S. Gordon, J. H. Jensen, S. Koseki, N. Matsunaga, K. A. Nguyen, S. J. Su, T. L. Windus, M. Dupuis, and J. A. Montgomery, J. Comput. Chem., 14, 1347-1363 (1993).

10. http://www.msg.ameslab.gov/GAMESS/GAMESS.html

11. B. M. Bode and M. S. Gordon, J. Mol. Graphics Modell., 16, 133-138 (1998).

12. L. J. Farrugia, J. Appl. Crystallogr., 30, 565 (1997). 
13. L. R. Kahn, P. J. Hay, and R. D. Cowan, J. Chem. Phys., 68, 2386-2397 (1978).

14. T. H. Dunning, Jr., J. Chem. Phys., 90, 1007-1023 (1989).

15. https://bse.pnl.gov/bse/portal

16. D. Feller, J. Comput. Chem., 17, 1571-1586 (1996).

17. K. L. Schuchardt, B. T. Didier, T. Elsethagen, L. Sun, V. Gurumoorthi, J. Chase, J. Li, and T. L. Windus, J. Chem. Inf. Model., 47, 1045-1052 (2007).

18. A. D. Becke, J. Chem. Phys., 98, 5648-5652 (1993).

19. C. Lee, W. Yang, and R. G. Parr, Phys. Rev. B: Condens. Matter Mater. Phys., 37, 785-789 (1988).

20. P. J. Stephens, F. J. Devlin, C. F. Chabalowski, and M. J. Frisch, J. Phys. Chem., 98, 11623-11627 (1994).

21. A. P. Zazhogin, A. I. Komyak, and D. S. Umreiko, Zh. Prikl. Spektrosk., 75, No. 5, 729-732 (2008).

22. L. V. Kobets, G. N. Klavsut', and D. S. Umreiko, Zh. Neorg. Khim., 26, 173-178 (1981).

23. M. Tranquille and M. T. Forel, Spectrochim. Acta, Part A, 28, 1305-1320 (1972).

24. W. A. de Jong, R. J. Harrison, J. A. Nichols, and D. A. Dixon, Theor. Chem. Acc., 107, 22-26 (2001).

25. J. R. Ferraro and A. Walker, J. Chem. Phys., 45, 550-553 (1966).

26. M. Tsuboi and I. C. Hisatsune, J. Chem. Phys., 57, 2087-2093 (1972).

27. R. M. Silverstein, F. X. Webster, and D. J. Kiemle, Spectrometric Identification of Organic Compounds, John Wiley \& Sons, Hoboken, NJ (2005).

28. F. A. Cotton, R. Francis, and W. D. Horrocks, Jr., J. Phys. Chem., 64, 1534-1536 (1960).

29. H. D. Bist, J. Mol. Spectrosc., 27, 542-544 (1968). 